\title{
A model of viral wheeze in nonasthmatic adults: symptoms and physiology
}

\author{
M.C. Mckean*, M. Leech*,\#, P.C. Lambert ${ }^{\top}$, C. Hewitt ${ }^{+, \#}$, S. Myint ${ }^{+}$, M. Silverman*
}

\begin{abstract}
A model of viral wheeze in nonasthmatic adults: symptoms and physiology. M.C. Mckean, M. Leech, P.C. Lambert, C. Hewitt, S. Myint, M. Silverman. CERS Journals Ltd 2001.

ABSTRACT: Episodic wheezing associated with viral infections of the upper respiratory tract (URT) is a common problem in young children but also occurs in adults. It is hypothesized that an experimental infection with human coronavirus $(\mathrm{HCoV})$, the second most prevalent common cold virus, would cause lower respiratory tract (LRT) changes in adults with a history of viral wheeze.

Twenty-four viral wheezers (15 atopic) and 19 controls (seven atopic) were inoculated with $\mathrm{HCoV} 229 \mathrm{E}$ and monitored for the development of symptoms, changes in airway physiology and provocative concentration of methacholine causing a $20 \%$ fall in forced expiratory volume in one second (FEV1) (PC20). At baseline, viral wheezers were similar to controls in $\mathrm{PC} 20$ (mean \pm SD $\log _{2} \mathrm{PC} 20$ : $5.1 \pm 1.9$ and $5.8 \pm 1.4 \mathrm{~g} \cdot \mathrm{L}^{-1}$, respectively) but had a lower FEV1 than controls (mean \pm SD $85.8 \pm 11.4$ and $95.6 \pm 13.2 \%$ predicted, respectively $p<0.05$ ). Nineteen viral wheezers and 11 controls developed colds. Viral wheezers with colds reported significantly more URT symptoms than controls (median scores (interquartile range): $24(10-37)$ and $6(4-15)$, respectively $p=0.014)$. Sixteen viral wheezers and no controls reported LRT symptoms (wheeze, chest tightness and shortness of breath). The viral wheezers with colds had small $(3-4 \%)$ reductions in FEV1 and peak expiratory flow on days with LRT symptoms (days 3-6), but a progressive reduction in $\mathrm{PC} 20$ from baseline on days 2, 4 and 17 after inoculation (by $0.82,1.35$ and 1.82 doubling concentrations, respectively). The fall in PC20 affected both atopic and nonatopic subjects equally. There were no changes in FEV1 or PC20 in controls.

An adult model of viral wheeze that is independent of atopy and therefore, of classical atopic asthma was established. Eur Respir J 2001; 18: 23-32.
\end{abstract}

\begin{abstract}
Depts of * Child Health, "Epidemiology and Public Health, ${ }^{+}$Microbiology and Immunology, and ${ }^{\#}$ Centre for Mechanisms of Human Toxicity, University of Leicester, Leicester, UK.
\end{abstract}

Correspondence: M.C. Mckean, Children's Asthma Centre, Dept of Child Health, University of Leicester, Robert Kilpatrick Clinical Sciences Building, Leicester Royal Infirmary, Leicester LE2 7LX, UK.

Fax: 441162525846

Keywords: Paediatrics viral infection

wheezing

Received: August 172000

Accepted after revision January 19 2001

This study was supported by the National Asthma Campaign (UK), GlaxoWellcome (UK), Merck Sharpe Dohme (UK) and the Midlands Asthma and Allergy Research Association (UK).
A growing body of evidence suggests that recurrent wheezing in early childhood in association with viral infection of the respiratory tract is distinct from atopic asthma in many ways [1]. A neonatal cohort study in Tucson, AZ, USA, which has reported findings at the age of $6 \mathrm{yrs}$, suggests that there are at least two different prognostic categories of preschool wheeze with distinctive risk factors [2]. One group ("persistent wheezers") initially suffered wheeze during viral infections, but wheezing persisted into school age in association with risk factors characteristic of classical, atopic asthma. Another group ("transient wheezers") also suffered wheeze during viral infections but seemed to outgrow their symptoms by the age of 6 yrs. A large cohort of wheezing children followed for $25 \mathrm{yrs}$ in Aberdeen, UK, found that although some individuals with childhood wheezing confined to episodes of viral upper respiratory tract infection (URTI) ("episodic viral wheezing") continued to wheeze into adulthood, they had less atopy, less severe wheeze and less likelihood of receiving corticosteroid therapy than classical childhood asthmatic wheezers [3]. These data strongly suggest that there is a clinical entity of viral wheeze in children and adults that is distinct from classical, atopic asthma.

Other studies indirectly support the existence of different wheezing phenotypes. Two studies of the effectiveness of corticosteroids in childhood episodic viral wheeze found no evidence to support the use of prophylactic inhaled corticosteroids in preventing or improving symptoms [4]. A study of the cells in bronchoalveolar lavage fluid of children with viral wheeze found no evidence of chronic inflammation during asymptomatic periods when compared with atopic asthmatics, whereas the latter had increased eosinophil and mast cell numbers [5]. These studies strongly suggest that different pathophysiological mechanisms underlie episodic viral wheeze and classical atopic asthma. Thus far, these mechanisms have been investigated using experimental infections that have focused on classical asthmatic or allergic adults, employing rhinovirus (RV) [6-10].

Human coronavirus ( $\mathrm{HCoV}$ ) is the second most prevalent of the common cold viruses $[11,12]$. It is associated with wheeze in asthmatic adults [13] and school-aged children [14], where $50 \%$ and $80 \%$ of 
exacerbations are triggered by proven viral URTIs, respectively. $\mathrm{HCoV}$ is also associated with wheeze in preschool children [12]. It has not been established if $\mathrm{HCoV}$ increases bronchial responsiveness in susceptible individuals, or whether it is a suitable virus to develop an experimental model to study viral wheezing. It is particularly important to examine this possibility, as the clinical pattern of disease in this virus appears to differ from other respiratory viruses [14].

Because experimental infection and invasive investigations are unethical in young children, an adult model is necessary to begin to understand the mechanisms operating in acute episodes of viral wheeze, although the mechanisms may not be identical in preschool children. It was hypothesized that an experimental infection with $\mathrm{HCoV}$ in adults with a history of viral wheeze would cause lower respiratory tract symptoms (including wheeze) and an increase in airway responsiveness, typical of a wheezing illness.

\section{Methods}

\section{Subjects}

Forty-four nonsmoking adults were recruited to the study, which lasted from May to November in 1997 and 1998. Nineteen were healthy volunteers recruited through local advertisements. Twenty-five viral wheezers were recruited from three local university health centres. Questionnaires were sent to 610 students who had consulted a doctor with a history of wheezing during URTIs or were known to have been prescribed inhaled bronchodilators but not corticosteroids. Of 111 replies, 25 gave a history of $\geqslant 2$ episodes of wheeze with URTI in the last 2 yrs, but not exerciseinduced wheeze, nocturnal or early morning wheeze or cough, allergen (dust, pollen, animal) induced wheeze, or wheeze in response to cold air. The mean duration (range) of symptoms was $12(3-25)$ yrs. Only one subject had previously been labelled as asthmatic. None were taking inhaled corticosteroids but 14 used occasional $\beta_{2}$-agonists, and none had been admitted to hospital with a respiratory illness in the previous 5 yrs. No subject had suffered a URTI in the month preceding participation in the study.

An assessment of atopic status was made by determining the skin-prick test response to Dermatophagoides pteronyssinus, cat fur and six grass pollens compared with histamine positive and saline negative controls (Soluprick, ALK Albello, Reading, UK). Any past history of allergic disease (eczema, allergic rhinitis and allergy to animals) was also recorded but subjects were classified as atopic on the basis of $\geqslant 1$ positive skin-prick test, defined by a skin weal $>2 \mathrm{~mm}$ in diameter above the negative control.

The study was approved by the Leicestershire Health Authority Research Ethics Committee and written informed consent was obtained from all participants.

\section{Study design}

The study involved four visits to the Clinical Trials Unit, Leicester Children's Asthma Centre. Baseline physiological measurements were carried out on day 0 , immediately preceding virus inoculation. Repeat measurements were made 2, 4 and 17 days after inoculation at the same time of morning $( \pm 2 h)$. Subjects completed daily symptom diaries and carried out electronic spirometry at home during the course of the study. As the principal aim was to study mechanisms underlying LRT symptoms, subjects were categorized based on their symptoms. Laboratory confirmation of viral infection was used as an adjunct to validate the model and assist categorizing subjects with mild symptoms.

\section{Home monitoring}

Daily morning forced expiratory volume in one second (FEV1) and peak expiratory flow (PEF) manoeuvres were performed by the subjects using Vitalograph 2110 Spirometers (Vitalograph, Buckingham, UK). Subjects were instructed on spirometry and the best of two attempts within $0.2 \mathrm{~L}$ of each other was recorded according to American Thoracic Society guidelines [15]. The diary categorized symptoms into upper and lower respiratory, cough and systemic symptoms, based on the validated score of JACKSON et al. [16]. URT symptoms included nasal discharge, nasal blockage, sneezing and sore throat. LRT symptoms included wheeze, chest tightness and shortness of breath. Systemic symptoms included fever, headache, chills and malaise. Each was graded from 0 (absent) to 3 (severe). Cough was recorded separately.

Symptom diaries were assessed blind by one of the authors (M. Silverman), in order to confirm symptomatic colds which were categorized as definite (URT scores $\geqslant 2$ above a zero baseline on each of two consecutive days from day $2-6$ ), possible (scores $\geqslant 1$ above zero baseline, or scores $\geqslant 2$ above a variable baseline on two consecutive days from day $2-6$ ), and absent. The baseline was taken as the score on day 0 .

\section{Virus inoculation}

HCoV 229E (American Type Culture Collection, Rockville, MD, USA) was cultured according to standards of good laboratory practice in human embryonic lung fibroblasts. An inoculum was prepared as previously described [17] and was tested for safety according to the criteria of GWALTNEY et al. [18]. Inoculation was performed using $1 \mathrm{~mL}$ of $\mathrm{HCoV}$ 229E suspension (200 tissue culture infective doses (TCID50) per $\mathrm{mL}$ ) instilled into each nostril, half by pipette and half by atomizer (Hoechst, Frankfurt, UK) on day 0 of the study.

\section{Physiological measurements}

On each test day, baseline FEV1 and PEF were recorded (Vitalograph 2120 Spirometer using the Spirotrac software, Vitalograph Ltd, Buckingham, UK). Bronchial challenge was performed with 
methacholine (Nova Laboratories, Leicester, UK) stored at $4{ }^{\circ} \mathrm{C}$ and warmed to room temperature before nebulization (Wright's nebulizer output $0.13 \mathrm{~mL} \cdot \mathrm{min}^{-1}$ ) [19]. After nebulization of the normal saline diluent, serial doubling concentrations of methacholine ranging $1-128 \mathrm{mg} \cdot \mathrm{mL}^{-1}$ were given by tidal breathing for $2 \mathrm{~min}$ at $5 \mathrm{~min}$ intervals, with a noseclip in place, through a mouthpiece. The response was measured as FEV1. During the methacholine challenges, single measurements of FEV1 were made $90 \mathrm{~s}$ after each dose. The tests were discontinued if FEV1 decreased by $>20 \%$ from baseline or when a methacholine concentration of $128 \mathrm{mg} \cdot \mathrm{mL}^{-1}$ had been administered, whichever was the earlier. The provocative concentration causing a 20\% drop in FEV1 (PC20) was calculated by linear interpolation from the FEV1- $\log _{10}$ methacholine concentration curve. At the end of the tests, subjects inhaled $200 \mu \mathrm{g}$ of albuterol from a metered-dose inhaler plus Volumatic spacer (GlaxoWellcome, UK).

\section{Confirmation of viral infection}

Laboratory confirmation of symptomatic colds was based on two assessments. Firstly, viral ribonucleic acid (RNA) was identified by reverse transcriptasepolymerase chain reaction (RT-PCR) in nasal lavage fluid, and throat and nose swabs taken on days 2 and 4 postinoculation. This method was derived from a nested RT-PCR described previously, which has been validated as being more sensitive than tissue culture [20]. The throat swab was taken from the posterior pharynx and tonsil bed, and the nose swab from the inferior turbinate. Both were placed immediately into phosphate-buffered saline containing ribonuclease (RNAse) inhibitor and stored at $-70^{\circ} \mathrm{C}$. The nasal lavage involved the subjects sitting with their necks extended to $45^{\circ}$ while warm phosphate-buffered saline was introduced into one nostril with the other occluded [21]. During the process the subject occluded the palate by positive oral pressure so that the wash remained in the nasal cavity for $10 \mathrm{~s}$ before being expelled into a sterile receptacle. A total of $10 \mathrm{~mL}$ in aliquots of $2.5 \mathrm{~mL}$ was inserted alternately in each nostril, $1 \mathrm{~mL}$ of mixed nasal wash was then removed and stored at $-70^{\circ} \mathrm{C}$ for later RT-PCR analysis.

The second method of confirmation was by seeking a rise in $\mathrm{HCoV}$ antibody titre using an anti-HCoV antibody enzyme-linked immunosorbent assay (ELISA) based on a previously described method [22]. Blood was taken on days 0 and 17 and serum separated and store at $-70^{\circ} \mathrm{C}$ until analysed. A significant rise in antibody over this period was defined as greater than the upper 95\% confidence interval (CI) for the mean ratio of antibody levels between 17 paired samples of sera taken from noninfected adults, 17 days apart.

"Wild" colds caught in the first week of this study were excluded by analysis of nose swabs placed in viral transport medium on days 2 and 4, and set up for routine culture for respiratory viruses (rhinovirus, respiratory syncytial virus (RSV), adenovirus, influenza viruses $\mathrm{A}$ and $\mathrm{B}$, parainfluenza viruses 1, 2, and 3). Later "wild" colds were only identified by scoring symptoms in the manner described above.

\section{Statistical analysis}

The distribution of subject characteristics (sex and atopy), symptomatic colds and laboratory proven colds between subject groups was studied by a Chisquared test. An independent samples unpaired t-test was used to analyse the age difference between groups. Analysis of outcome data was based upon the categories of symptomatic colds defined as definite, possible, and no cold. Total symptom scores $>17$ days and peak symptom scores were analysed nonparametrically with the Mann-Whitney U-test and the study day on which maximum symptoms occurred, which were normally distributed, by an unpaired t-test. A summary measure for each symptom, percentage of days with the symptom, was used to reflect duration of symptoms. Analysis of summary measures was by Mann-Whitney U-test or the two samples Wilcoxon test, as required. The relationship between URT and lower respiratory tract (LRT) symptoms in those who developed LRT symptoms was assessed by Spearman's correlation. The Chisquared test was also used to assess the relationship between atopy and wheeze.

Normalized FEV1, and PEF data [23] were compared using the independent samples unpaired t-test. In order to assess the effect that the presence of each symptom had on PEF and FEV1, multilevel models were used. Multilevel models take into account the correlation between repeated observations on the same subject by incorporating random effects into the linear model. A separate analysis was performed for each symptom that included terms for the mean FEV1 and PEF in each group in the absence of symptoms and the change in FEV1 and PEF when the symptom was present. Controls did not suffer LRT symptoms, hence estimates could not be obtained.

$\mathrm{Log}_{2}$ transformation of PC20 methacholine measurements was used prior to analysis in order to represent changes as doubling doses. Paired and unpaired t-tests for related and independent groups were used for within and between group analysis, respectively. Association between change in $\log _{2} \mathrm{PC} 20$ and LRT symptom score was assessed by Spearman's rank correlation. The $\mathrm{PC}_{20}$ data were censored by designating those subjects unresponsive to $128 \mathrm{mg} \cdot \mathrm{mL}^{-1}$ as responsive at this concentration, for the purpose of analysis.

\section{Results}

The viral-wheeze group was slightly younger and had more females than the control group (table 1). The greater proportion of atopic subjects in the viralwheeze group did not reach statistical significance (table 1). Only one nonatopic subject reported a history of allergic disease: "eczema as a baby". Four of seven atopic controls and six of 15 atopic viral wheezers had a positive history of nonpulmonary 
Table 1.-Entry characteristics of study subjects

\begin{tabular}{|c|c|c|c|c|}
\hline \multirow[t]{2}{*}{ Characteristic } & \multirow[t]{2}{*}{ Controls } & \multirow[t]{2}{*}{ Viral wheezers } & \multicolumn{2}{|c|}{ Difference in } \\
\hline & & & Proportions \% (95\% CI) & Mean $(95 \% \mathrm{CI})$ \\
\hline \multicolumn{5}{|l|}{ Categorical data } \\
\hline Subjects n & 19 & 24 & & \\
\hline Bronchodilator use & $0(0)$ & $14(58)$ & & \\
\hline Sex M:F (\% M) & $12: 7(63)$ & $6: 18(25)$ & $38(8-68)^{*}$ & \\
\hline Atopy & 7 (37) & $15(62)$ & $25(-4-56)$ & \\
\hline \multicolumn{5}{|l|}{ Continuous data } \\
\hline Age yr & $28 \pm 5$ & $24 \pm 5$ & & $4(1-7)^{* *}$ \\
\hline Last URTI (months ago) & $7 \pm 3.8$ & $5 \pm 3.7$ & & $2(-1-4)$ \\
\hline FEV1 \% pred & $95.6 \pm 13.2$ & $85.8 \pm 11.4$ & & $9.8(2.3-17.3)^{*}$ \\
\hline PEF \% pred & $118.8 \pm 41.2$ & $104.3 \pm 21.8$ & & $14.4(-6.9-34.2)$ \\
\hline $\log _{2} \mathrm{PC} 20 \mathrm{~g} \cdot \mathrm{L}^{-1}$ & $5.8 \pm 1.4$ & $5.1 \pm 1.9$ & & $0.7(-0.4-1.7)$ \\
\hline
\end{tabular}

Values are presented as $\mathrm{n}(\%)$ for categorical data and mean \pm SD for continuous data. M: male; F: female; CI: confidence interval; URTI: upper respiratory tract infection; FEV1: forced expiratory volume in one second; PEF: peak expiratory flow; PC20: provocative concentration of methacholine causing a $20 \%$ fall in FEV1. *: $p<0.05 ; * *: p<0.01$

allergic disease. Viral wheezers had statistically insignificant lower baseline normalized PEF and a significantly lower FEV1 than controls (table 1). There was no significant difference in the $\log _{2} \mathrm{PC} 20$ between viral wheezers and controls at baseline (table 1 ) and almost all were well outside the "asthmatic range" $\left(\log _{2} \mathrm{PC} 20<3 \mathrm{~g} \cdot \mathrm{L}^{-1}\right)$ except for three viral wheezers who were atopic $\left(\log _{2} \mathrm{PC} 20\right.$ was equal to $\left.2.9,1.2,2.3\right)$. Atopic viral wheezers had a significantly lower $\log _{2} \mathrm{PC} 20$ at baseline than nonatopic viral wheezers $\left(\right.$ mean \pm SD $\log _{2} \mathrm{PC}_{20}$ was $4.5 \pm 1.9$ and $6.2 \pm 1.4 \mathrm{~g} \cdot \mathrm{L}^{-1}$ respectively, $\mathrm{p}=0.027$ )

One subject was excluded because of incomplete home monitoring. There were 27 "definite", four "possible" and 12 "no" colds (table 2). Laboratory analysis by RT-PCR and ELISA identified evidence of $\mathrm{HCoV}$ infection in 24, three and three subjects in these groups, respectively. All volunteers had detectable antibody levels at day 0 . The mean $(95 \% \mathrm{CI})$ of the ratios between paired antibody levels in 17 noninfected controls was $1.00(0.75,1.25)$ absorbance values. The mean antibody ratio $(95 \% \mathrm{CI})$ of convalescent to acute samples for those with significant rises (i.e. above the upper $95 \% \mathrm{CI}$ of the 17 noninfected controls was 1.25$)$ was $1.50(1.34,1.66)$ whereas for those with no significant rise it was $1.10(1.06,1.14)$. Pre-existing antibody levels did not relate to symptomatic colds (mean \pm SD absorption values at 1:10 serum

Table 2.- Response to human coronavirus 229E infection

\begin{tabular}{lccccc}
\hline Group & $\begin{array}{c}\text { Clinical } \\
\text { URTI }\end{array}$ & $\mathrm{n}$ & $\begin{array}{c}\text { PCR } \\
+\mathrm{ve}\end{array}$ & $\begin{array}{c}\text { ELISA } \\
+\mathrm{ve}\end{array}$ & $\begin{array}{c}\text { Total lab. } \\
\text { positives }\end{array}$ \\
\hline Viral & Definite & $19^{*}$ & $13 / 19$ & $10^{+}$ & 16 \\
Wheeze & No & 5 & 2 & $0^{\star}$ & 2 \\
Control & Definite & 8 & 8 & $6^{\#}$ & 8 \\
& Possible & 4 & 3 & 0 & 3 \\
& No & 7 & 1 & $0^{\S}$ & 1 \\
\hline
\end{tabular}

URTI: upper respiratory tract infection; ELISA: enzymelinked immunsorbent assay, + ves have a ratio $>1.25$; PCR: polymerase chain reaction. ${ }^{+}: \mathrm{n}=17 ;{ }^{\uparrow}: \mathrm{n}=3 ;{ }^{*}: \mathrm{n}=7 ;{ }^{\S}$ : $\mathrm{n}=1$. *: $\mathrm{p}<0.05$ for difference between viral wheeze and control groups. dilution were $0.56 \pm 0.15$ and $0.61 \pm 0.15$ for colds and no colds, respectively) or to rise in antibody levels after experimental infection (mean $\pm \mathrm{SD}$ absorption values at $1: 10$ serum dilution were $0.68 \pm 0.10$ and $0.60 \pm 0.18$ for those with and without a significant antibody rise, respectively). The viral-wheeze group had a greater proportion of definite colds than the control group, despite receiving the same titre of virus. The three controls with RT-PCR positive "possible" colds were felt to have mild colds and were added to the "definite" group for analysis. Nine "wild" colds were thought to have occurred in the latter half of the study and one subject suffered a broken nose in the second week of the study, hence diary data and physiology from these periods and day 17 PC20 methacholine were excluded. One viral wheeze subject with a cold failed to attend on day 2 of the study. Swabs for culture of respiratory viruses (other than $\mathrm{HCoV}$ ) taken on days 2 and 4 were all negative.

In two viral wheezers and one control without colds, RT-PCR of nasal samples were positive (table 2), representing asymptomatic infections. As the purpose of this model was to examine the response to viral URTI, these individuals remained in the "no cold" group.

\section{Symptoms}

The viral-wheeze group reported significantly more severe URT and systemic symptoms that were of slightly longer duration than the control group (table 3). The temporal pattern of URT symptoms was similar between groups (fig. 1), with the mean \pm SD peak URT symptoms for controls and viral wheezers occurring at $3.4 \pm 1.5$ days and $3.6 \pm 1.4$ days, respectively $(\mathrm{p}=0.67)$.

The diaries confirmed that the controls did not suffer LRT symptoms, whereas 16 of the 19 viral wheezers suffered LRT symptoms. LRT symptoms were temporally related to the URT symptoms (fig. 1) with the onset of LRT symptoms following the onset of URT symptoms by $24 \mathrm{~h}$. There was a weak correlation between the peak URT and LRT scores 
Table 3. - Symptomatic response to human coronavirus $229 \mathrm{E}$ inoculation

\begin{tabular}{|c|c|c|c|c|}
\hline & \multirow[t]{2}{*}{ Symptoms } & \multicolumn{3}{|c|}{ Symptom scores in all those with URTI } \\
\hline & & Viral wheezers & Controls & p-value \\
\hline \multirow{5}{*}{$\begin{array}{l}\text { Subjects n } \\
\text { Total scores }\end{array}$} & & 19 & 11 & \\
\hline & URT & $24(10-37)$ & $6(4-15)$ & 0.014 \\
\hline & LRT & $6(2-19)$ & $0(0-0)$ & $<0.001$ \\
\hline & Systemic & $9(4-18)$ & $1(0-8)$ & 0.048 \\
\hline & Cough & $4(0-14)$ & $0(0-5)$ & 0.134 \\
\hline \multirow[t]{8}{*}{ Symptomatic days* } & Rhinorrhea & $23(18-35)$ & $18(9-38)$ & 0.32 \\
\hline & Blocked nose & $29(10-41)$ & $29(18-62)$ & 0.38 \\
\hline & Sneeze & $26(12-43)$ & $12(0-44)$ & 0.24 \\
\hline & Sore throat & $26(4-53)$ & $18(6-35)$ & 0.39 \\
\hline & Wheeze & $22(0-37)$ & $0(0-0)$ & $<0.001$ \\
\hline & Tight chest & $18(4-43)$ & $0(0-0)$ & $<0.001$ \\
\hline & Shortness of breath & $12(4-35)$ & $0(0-3)$ & $<0.001$ \\
\hline & Cough & $23(0-59)$ & $18(0-38)$ & 0.36 \\
\hline
\end{tabular}

Data are presented as median (interquartile range). URTI: upper respiratory tract infection; URT: upper respiratory tract; LRT: lower respiratory tract. *: expressed as proportion of record period rather than total, to allow for missing data or data excluded due to "wild" colds (see text).

$\left(r_{s}=0.513,95 \% \mathrm{CI}=-0.01-0.82, \mathrm{p}=0.05\right)$, but not between total URT and LRT symptom scores $\left(\mathrm{r}_{\mathrm{s}}=0.16,95 \% \mathrm{CI}=-0.38-0.61, \mathrm{p}=0.56\right)$ in those viral wheezers with LRT symptoms.

Neither upper nor lower respiratory tract symptom severity was related to atopic status. For URT symptoms, median (upper quartile (UQ), lower quartile (LQ)) total scores were $27(22-37)$ and $21(8-38)$ in nonatopics and atopics, respectively $(\mathrm{p}=0.22)$. Among the 19 subjects in the viral-wheeze group who had a definite URTI, nine of 12 atopics and all seven of the nonatopics actually developed LRT symptoms $(\mathrm{p}=0.15)$, and their LRT symptom severity was not related to atopic status. Median (UQ, LQ) total LRT scores were $14(5-24)$ and $5(1-18)$ in nonatopics and atopics, respectively $(\mathrm{p}=0.27)$.

\section{Lung function}

FEV1 tended to be lower in the viral-wheeze group on symptom free days compared to controls (FEV1 on days without nasal discharge, mean $(95 \% \mathrm{CI})$ was $83 \%$ $(78-89)$ and $94 \%(89-105)$, respectively). PEF measurements were similar in the two groups on symptom free days (PEF on days without nasal discharge, mean $(95 \% \mathrm{CI})$ were 105\% $(99-111)$ and $106 \%(9-122)$, respectively). For all symptoms, on days when symptoms were present there was a reduction in FEV1 for the viral-wheeze group (table 4). The largest reductions in FEV1 were associated with cough, shortness of breath and wheeze. The largest changes in PEF were associated with shortness of breath, sore throat, chest tightness and cough. The presence of symptoms in the control group made little difference to the levels of lower FEV1 and PEF. However, due to the relatively small numbers when comparing the changes in the viral-wheeze group to the controls, the only change that was formally significant was for the reduction in PEF in the presence of cough $(\mathrm{p}=0.04)$.

\section{Bronchial responsiveness}

There were no significant changes in $\log _{2} \mathrm{PC} 20$ during the study in viral wheezers without a cold or in controls with or without a cold. The viral-wheeze group with a cold had a significant increase in bronchial responsiveness on days 2 and 4 shown by a decrease in $\mathrm{PC}_{20}$ by 0.82 and 1.35 doubling concentrations from baseline respectively (fig. 2). This persisted to day 17 where the PC20 had dropped by 1.82 doubling concentrations from baseline. The PC20 of the viral wheezers was progressively lower than the controls during the study and this was significantly lower on days 4 and 17 (fig. 2). Even after making conservative Bonferonni corrections the results were still significant.

The total LRT score (excluding cough), reflecting severity of the wheezing illness in the viral wheezers, was found to correlate with change in $\log _{2} \mathrm{PC} 20$ on day $4\left(r_{s}\right.$ was $\left.0.54, p=0.02\right)$ but not on days 2 and $17\left(r_{s}\right.$ was 0.01 and $0.20, \mathrm{p}=0.98$ and 0.46 , respectively). The small decreases in FEV1 and PEF seen during symptoms coincided with the decrease in PC20 on days 2 and 4, but symptoms FEV1 and PEF had resolved by day 17 when the change in PC20 was at its greatest.

In both atopic and nonatopic viral wheezers with a cold, PC20 decreased progressively during the study and the difference which had been present at baseline became less marked and was statistically insignificant by day 2 (fig. 3).

\section{Discussion}

It has been have shown that experimental $\mathrm{HCoV}$ 229E infection causes LRT symptoms and a prolonged increase in bronchial responsiveness to methacholine in adults with a prior history of wheeze during episodes of viral URTI; this does not occur in healthy control subjects. The increase in bronchial responsiveness persisted beyond the presence of LRT symptoms and was independent of atopy. This potential for excessive airway narrowing confirms 

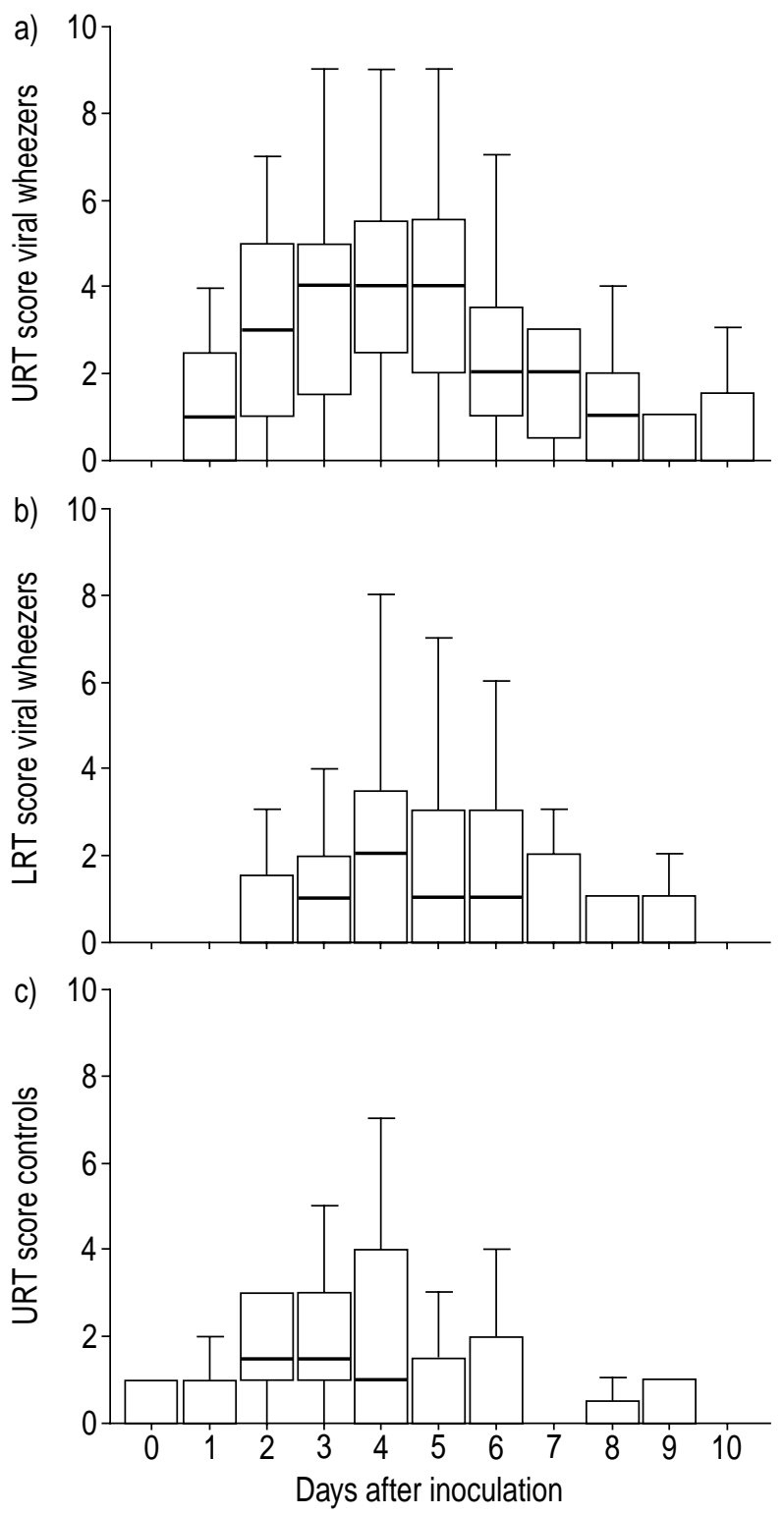

Fig. 1. - Time course of upper respiratory tract (URT) symptoms for a) viral wheezers, b) lower respiratory tract (LRT) symptoms for viral wheezers and c) control subjects. Boxes represent the median and 25 th and 75 th centiles, whiskers represent the minimum and maximum values.

that HCoV 229E, which causes trivial URT symptoms in most people, can lead to LRT effects in susceptible individuals. Therefore, an experimental model of viral wheeze has been established in adult subjects.

The wheezing subjects in this study did not have classical asthma, having no intercurrent symptoms, no bronchial hyperresponsiveness at baseline, no requirement for corticosteroid therapy and no current doctordiagnosis of asthma. During episodes of wheezing, some used $\beta$-agonists alone. This model is important as it will allow for the investigation of the effects of common respiratory viruses on the LRT in subjects without symptoms, suggesting chronic inflammation of the LRT. There are, however, technical considerations in such a model.

\section{Evidence of viral infection}

This model used a virus passaged in cell culture and inoculated into the nose in high titre. It is theoretically possible that the use of a virus that may have been attenuated by laboratory growth and applied in an artificial way to the nose may result in a different illness to that seen in "wild" infections, but previous experimental inoculation studies have confirmed that the disease spectrum is that of wild-type infection [24, 25]. Additionally, such a model lessens the problem of virus heterogeneity and timing of onset of infection that could make the detailed study of the physiological and biological responses to "wild" infections very difficult.

All subjects were exposed to active virus and viral antigens, and there were no true vehicle controls or inactivated virus controls, as would have been ideally included. The use of ultraviolet inactivated virus as a control was logistically impossible in the study, but would have allowed for the distinction between the nasal response to viral antigen and cell culture contaminants and true nasal infection. Subjects who did not develop a cold may have had an asymptomatic infection and generated an immune response to the virus. Indeed, three asymptomatic individuals had evidence of viral replication by positive RT-PCR in nasal samples 2-4 days after inoculation. The alternative explanation of contamination leading to falsepositive results is unlikely. Two subjects were sampled in isolation making contamination at this stage highly unlikely, and none of their reverse transcriptasenegative controls became positive during RT-PCR, making contamination during the assay unlikely. It seems likely that the three did have asymptomatic colds, a phenomenon that has been described previously [24, 26].

The failure to identify virus in all subjects with colds is a finding common to most experimental infections. Possible explanations include coincidental wild-type virus infection and false-negative RT-PCR results. Firstly, no evidence of the most common wild-type infections were found, although there was no means of differentiating coincidental wild-type $\mathrm{HCoV}$ 229E infection from the inoculated virus. There was however, a strong temporal relationship between inoculation and onset of symptoms, strongly suggesting that infections were indeed due to the experimental virus. Secondly, considering the possibility of false-negative RT-PCR results, three subjects with definite colds had no laboratory confirmation. There are several possible reasons why RT-PCR might not identify virus in all those with symptomatic colds, the most likely being natural RNAse in nasal samples which degrade the viral genome. In addition, even with due care during the PCR process, RNAse contamination will reduce the positive rates.

The lower rate ELISA positives compared with RTPCR implies either a lack of specificity of the RT-PCR assay or presence of viral antigen without infection $2-4$ days after inoculation. The RT-PCR is highly specific with primers designed to target the N-gene of $\mathrm{HCoV}$ only [20]. False-positives from contamination during the RT-PCR assay are unlikely as none were 
Table 4. - Difference in forced expiratory volume in one second (FEV1) and peak expiratory flow (PEF) between days with and without symptoms

\begin{tabular}{|c|c|c|c|c|c|c|}
\hline \multirow[t]{2}{*}{ Symptoms } & \multicolumn{2}{|c|}{$\Delta \mathrm{FEV}_{1}$ on days with symptoms } & \multirow[t]{2}{*}{ p-value* } & \multicolumn{2}{|c|}{ PEF on days with symptoms } & \multirow[t]{2}{*}{ p-value* } \\
\hline & Controls & Viral wheezers & & Controls & Viral wheezers & \\
\hline Runny nose & $-2(-6-2)$ & $-1(-4-1)$ & 0.86 & $2(-2-6)$ & $-1(-3-1)$ & 0.20 \\
\hline Blocked nose & $0(-3-3)$ & $-1(-3-1)$ & 0.46 & $0(-3-4)$ & $0(-2-3)$ & 0.85 \\
\hline Sneezing & $0(-3-3)$ & $-2(-4-0)$ & 0.31 & $2(-1-6)$ & $-1(-4-1)$ & 0.09 \\
\hline Sore throat & $-1(-4-2)$ & $-2(-4-0)$ & 0.49 & $-1(-5-2)$ & $-4(-6--2)$ & 0.23 \\
\hline Wheeze & & $-3(-7-1)$ & & & $-3(-5-0)$ & \\
\hline Chest tightness & & $-2(-4-0)$ & & & $-4(-6--2)$ & \\
\hline Short of breath & & $-4(-6--2)$ & & & $-4(-7--2)$ & \\
\hline Cough & $0(-4-3)$ & $-4(-6--2)$ & 0.08 & $1(-2-5)$ & $-3(-6--1)$ & 0.04 \\
\hline
\end{tabular}

Data are presented as mean difference $\Delta(95 \% \mathrm{CI})$ of $\%$ predicted values. $*$ : p-value represents a test for the difference in $\triangle$ FEV 1 and $\triangle \mathrm{PEF}$ between the two groups.

detected in the duplicate reverse transcript negative control samples. RT-PCR is a highly sensitive and specific assay that for $\mathrm{HCoV}$ detection is superior to serology [20]. This is borne out in a Southampton study of 292 reported virus induced exacerbations of asthma suffered by 108 children aged $9-11$ yrs [14]. RT-PCR identified $\mathrm{HCoV}$ in $21 \%$ of 80 available samples compared to $5 \%$ and $7 \%$ of 292 samples by culture and ELISA, respectively. It is certainly more sensitive than culture as $\mathrm{HCoV}$ does not grow on standard cell lines or produce easily recognizable cytopathic effects [20]. It is for this latter reason that culture was not attempted in these subjects. The persistence of viral RNA from the initial inoculum for $2-4$ days is highly unlikely in an environment containing abundant RNAse. The laboratory results back up the clinical data, with 27 of $31(87 \%)$ colds being laboratory positive compared to 3 of $12(25 \%)$ with no symptomatic URTI.

An alternative interpretation of the lower rate of ELISA positive results compared with RT-PCR, is false-negatives in the ELISA, for which there are

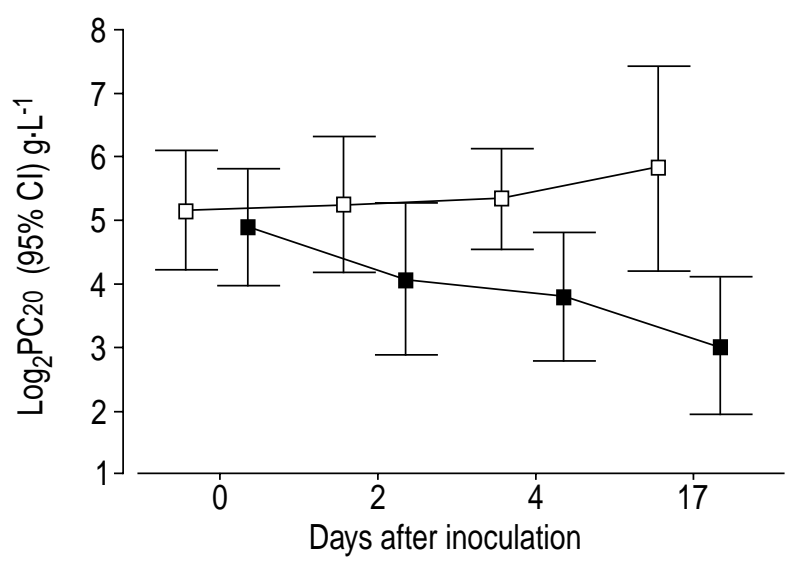

Fig. 2. - Mean $\log _{2}$ provocative concentration of methacholine causing a $20 \%$ fall in forced expiratory volume in one second (PC20) $(95 \%$ confidence interval $(\mathrm{CI})) \mathrm{g} \cdot \mathrm{L}^{-1}$ in viral-wheezers $(\mathbf{\square})$ and control subjects $(\square)$ with colds during the study. The significant decrease from baseline in the viral-wheeze group on days 2,4 and $17(\mathrm{p}=0.002,0.002,<0.001)$ was not seen in the controls $(\mathrm{p}=0.21,0.20,0.39)$. The viral wheezers had significantly lower $\log _{2} \mathrm{PC}_{20}$ than controls on days $4(\mathrm{p}=0.032)$ and $17(\mathrm{p}=0.007)$ but not on day $2(\mathrm{p}=0.156)$. several reasons. The ELISA is dependent on the quality of materials. Viral antigens were concentrated by ultracentrifugation and the secondary antibody was a rabbit antihuman immunoglobulin-G (IgG). Problems of nonspecific binding may interfere with the detection of significant changes in antibody. Future improvements may come from the preparation of purified antigen and the development of a specific anticoronavirus $229 \mathrm{E}$ antibody, which is not currently available. Also, the ELISA was conducted over a shorter period than reported previously [22] and some late but significant antibody rises may have been missed.

Although only small rises in antibodies were seen in those with symptomatic colds, they were statistically significant, exceeding the upper $95 \%$ CI for the mean ratio in repeat measurements (over 17 days) in a group of noninfected volunteers. It is generally accepted that $\mathrm{HCoV}$ infection is not strongly immunogenic and does not always cause a four-fold rise in antibody [20]. Indeed, a convalescent to acute ratio in serum of 1.3 has been used previously as a cut-off indicating significant infection [13]. There are only two main serotypes of $\mathrm{HCoV}$, both known to cause repeated infections in the same individuals [25]. In this respect, $\mathrm{HCoV}$ is

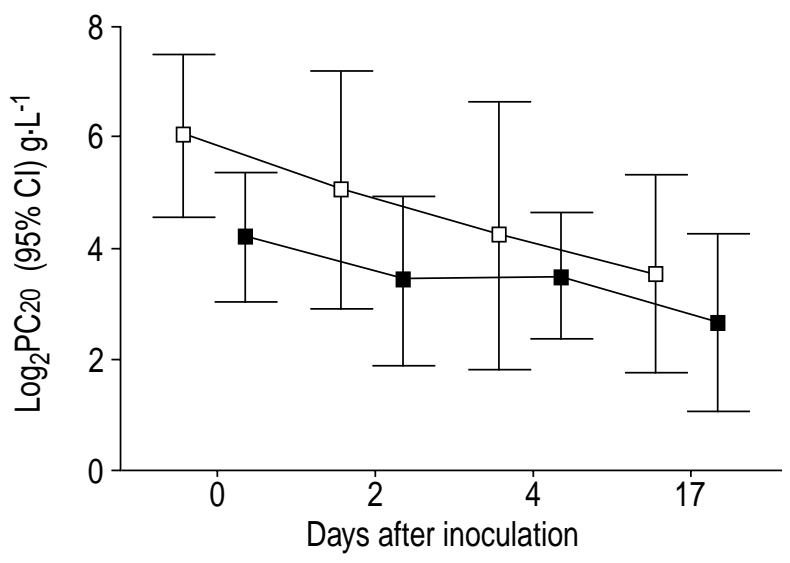

Fig. 3. - Mean $\log _{2} \mathrm{PC} 20$ provocative concentration of methacholine causing a $20 \%$ fall in forced expiratory volume in one second (PC20) $(95 \%$ confidence interval $(\mathrm{CI})) \mathrm{g} \cdot \mathrm{L}^{-1}$ in viral wheezers with (ם) and without $(\square)$ atopy. There was a significant difference at day $0(\mathrm{p}=0.039)$ but not on days 2,4 and $17(\mathrm{p}=0.153,0.475$, 0.424 , respectively). 
very different from RV, where there are several hundred known serotypes that have the ability to induce a four-fold rise in antibody levels in immune-naive individuals.

Serum antibody titre was not measured prior to inoculation, although baseline levels were assayed at a later date. It has been demonstrated that antibodies to HCoV slowly decline over a period of $12-18$ months after infection and that rechallenge with virus can lead to a repeat infection when antibodies are still detectable [25]. Indeed, in the volunteers, measurable antibodies at baseline did not relate to the clinical outcome, nor did pre-existing antibodies to $\mathrm{HCoV}$ attenuate the infection, as baseline antibody levels did not relate to the severity of infection. Clearly, the immune response to $\mathrm{HCoV}$ infection is complex and differs from the response to $\mathrm{RV}$.

\section{Design issues}

Subjects for this study were recruited from health centres attached to three local universities in order to obtain young and otherwise healthy adults. Patients known to wheeze but that were not on inhaled corticosteroids, were screened by questionnaire, and typical asthmatics excluded. As such, the subjects were biased only in that they were young, relatively healthy and reported mild illness. A 25-yr follow-up of school children with viral wheeze suggests that such subjects continue to exhibit relatively mild symptoms [3]. There is no reliable evidence that the subjects had viral wheeze as children, or that their current episodic symptoms mimic those of young children with episodic viral wheeze.

No difference in the change in airway responsiveness between atopics and nonatopics was found, defined the by skin-prick test. Only one viral wheezer with a negative skin-prick test had a history of possible atopic disease (eczema in infancy); reclassification of this subject as atopic made no difference to the outcome.

\section{Airway physiology}

This study is the first to establish that infection with $\mathrm{HCoV} 229 \mathrm{E}$ can increase bronchial responsiveness in susceptible individuals. The precise mechanisms of increased airway responsiveness are unknown but are likely to involve a complex interaction of different factors. One factor is airway wall structure, which alters airway geometry causing differences in the host response to constrictor stimuli [27]. In those experimental studies in which RV caused an increase in airway responsiveness [6-10] there was no accompanying decrease in FEV1, suggesting that mechanisms other than geometric are involved, although FEV1 alone is a rather crude measure of airway geometry. One study of 20 healthy volunteers with "wild" colds, three of which were due to coronavirus, demonstrated a small but significant decrease in FEV1 along with increased airway responsiveness [28]. In the present study, the lower baseline FEV1 in viral wheezers was not a significant factor in the difference in response to methacholine challenge between the two groups after viral inoculation. Indeed, at baseline there was no difference in $\mathrm{PC} 20$ between viral wheezers and controls despite the difference in FEV1. During the symptomatic phase there was a small decrease in airway calibre associated with cough, shortness of breath and wheeze, but this too cannot account for the progressive decline in $\mathrm{PC}_{2} 0$ at day 17 , well after lung function and symptoms had returned to normal. It can be concluded that the small changes in FEV1 were not responsible for the change in airway responsiveness. Whatever the mechanisms of the increased bronchial responsiveness, its occurrence in both atopic and nonatopic individuals, regardless of the small difference in baseline airway responsiveness, suggests that the subjects have a disorder which differs from classical atopic asthma.

The link between a URTI and increased bronchial responsiveness must involve subtle changes that can persist for some time. Several potential mechanisms have been suggested including LRT inflammation (reviewed by FoLKERTS et al. [29]), impairment of $\beta$-adrenoceptor and $\mathrm{M}_{2}$-muscarinic receptors leading to smooth muscle constriction [30], and persistence of virus in the LRT [31]. How these potential mechanisms relate to one another in the pathogenesis of LRT symptoms and changes in lung function during common respiratory virus infections, are still largely unknown.

\section{Pathogenesis of lower respiratory tract features}

The link between viral URTI and LRT symptoms could involve three different areas, LRT inflammation, viral factors and indirect links between the URT and LRT. There is much evidence linking inflammation to alterations in airway function in asthmatic individuals but none in adults with viral wheeze. Data gathered during an asymptomatic interval from children with viral wheeze do not support ongoing LRT inflammation [5], but there is little information on the acute inflammatory responses in these individuals, either in the URT or LRT. Models of virus induced asthma implicate neutrophils, eosinophils and lymphocytes in the inflammatory response which is thought to be central to the development of LRT symptoms [8, 32, 33]. Direct comparisons of the degree and type of inflammation together with measures of host response are required to fully explore the role of LRT inflammation in viral wheeze.

There may be qualitative differences in the site of viral infection between different hosts. If viruses can replicate in the LRT of wheezers but not in nonwheezers then direct infection could be a key factor. How such differences could occur is not known but may involve a complex interaction of virus and host defence mechanisms. Whether common respiratory viruses such as RV and HCV, which account for the majority of common cold infections, can replicate in the LRT is still controversial. There are some data to support this based on bronchoalveolar samples during experimental RV infection [34], but none yet for $\mathrm{HCoV}$.

Alternatively, the response seen in viral wheezers 
may simply reflect a predisposition to a quantitatively greater degree of virus replication, and by implication, inflammation in the URT. This could have a bearing on whether LRT infection occurs. Although RT-PCR of nasal samples in this study did not allow us to quantify the degree of virus replication, viral wheezers had significantly more severe URT and systemic symptoms than controls. Asthmatics have also been shown to report greater URT symptoms in experimental colds [8]. Whether this apparent predisposition to a more severe URT illness is related to the degree of epithelial infection or to an abnormal host response to a similar degree of infection in both the URT and LRT, is not known.

Whether or not LRT inflammation or infection occurs, there may also be indirect effects on the LRT from the infected and inflamed URT. Breathing through an inflamed URT is likely to alter the quality of inhaled air and may carry inflammatory products, such as cytokines and nitric oxide, to the LRT. If neural control of airway diameter is influenced by changes in the URT this too could result in LRT effects from an URTI. Finally, a systemic response to URT inflammation, such as T-cell activation or chemokine release, could lead to LRT effects if such cells and mediators can "home" to the LRT. There is little data supporting any of these indirect connections between URT and LRT, but abnormal responses occurring in these routes could contribute to developing wheeze during viral URTI.

\section{Implications}

A unique model of adult episodic viral wheeze with evidence of lower respiratory tract symptoms and deranged airway physiology has been developed. The model will be used to investigate the mechanisms that underlie the condition. It may allow for the testing of hypotheses regarding viral wheeze in general, to compare invasive with noninvasive techniques, and eventually to begin to explore the mechanisms of viral wheeze, as distinct to atopic asthma. Such an approach may enable a further understanding of the different phenotypes of wheeze and asthma that are being increasingly recognized in both children and adults.

\begin{abstract}
Acknowledgements. The authors would like to thank the Virus Laboratory, Leicester Royal Infirmary for their support with the culture of "wild" viruses, A. Wardlaw, J. Grigg (members of the Leicester University Viral Wheeze Group), and H. Pringle (Dept of Pathology, Leicester University) for their advice, and $\mathrm{S}$. Euden for technical assistance. C. Hewitt is supported by a Fellowship from the Midlands Asthma and Allergy Research Association.
\end{abstract}

\section{References}

1. Silverman M. Out of the mouths of babes and sucklings: lessons from early childhood asthma. Thorax 1993; 48: 1200 .
2. Martinez FD, Wright AL, Taussig LM, et al. Asthma and wheezing in the first six years of life. $N$ Engl J Med 1995; 332: $133-138$.

3. Godden DJS, Ross S, Abdalla M, et al. Outcome of wheeze in childhood. Symptoms and pulmonary function 25 years later. Am J Respir Crit Care Med 1994; 149: $106-112$.

4. Mckean MC, Ducharme F. Inhaled steroids for episodic viral wheeze in children. Cochrane Library, 1999.

5. Stevenson EC, Turner G, Heaney LG, et al. Bronchoalveolar lavage findings suggest two different forms of childhood asthma. Clin Exp Allergy 1997; 27: $1027-1035$.

6. Lemanske RF Jr, Dick EC, Swenson CA, Vrtis RF, Busse WW. Rhinovirus upper respiratory infection increases airway hyperreactivity and late asthmatic reactions. J Clin Invest 1989; 83: 1-10.

7. Cheung DE, Dick C, Timmers MC, de Klerk EP, Spaan WJ, Sterk PJ. Rhinovirus inhalation causes long-lasting excessive airway narrowing in response to methacholine in asthmatic subjects in vivo. Am J Respir Crit Care Med 1995; 152: 1490-1496.

8. Fraenkel DJ, Bardin PG, Sanderson G, Lampe F, Johnston SL, Holgate ST. Lower airways inflammation during rhinovirus colds in normal and in asthmatic subjects. Eur Arch Otorhinolaryngol 1995; 151: S879-S886.

9. Gern JE, Calhoun W, Swenson C, Shen G, Busse WW. Rhinovirus infection preferentially increases lower airway responsiveness in allergic subjects. $\mathrm{Am}$ J Respir Crit Care Med 1997; 155: 1872-1876.

10. Grunberg K, Smits HH, Timmers MC, et al. Experimental rhinovirus 16 infection: Effects on cell differentials and soluble markers in sputum in asthmatic subjects. Am J Respir Crit Care Med 1997; 156: 609616.

11. Isaacs D, Flowers D, Clarke JR, Valman HB, Macnaughton MR. Epidemiology of coronavirus respiratory infections. Arch Dis Child 1983; 58: 500 503.

12. McIntosh K, Chao RK, Krause HE, Wasil R, Mocega HE, Mufson MA. Coronavirus infection in acute lower respiratory tract disease of infants. $J$ Inf Dis 1974; 130: $502-507$.

13. Nicholson KG, Kent J, Ireland DC. Respiratory viruses and exacerbations of asthma in adults. $B M J$ 1993; 307: $982-986$.

14. Johnston SL, Pattemore PK, Sanderson G, et al. Community study of role of viral infections in exacerbations of asthma in 9-11 year old children. BMJ 1995; 310: 1225 - 1229 .

15. Crapo RO, Hankinson JL, Irvin C, et al. Standardization of spirometry: 1994 Update. Am J Respir Crit Care Med 1995; 152: 1107-1136.

16. Jackson GG, Dowling HF, Speisman IG, Boand AV. Transmission of the common cold under controlled conditions. 1. The common cold as a clinical entity. Arch Intern Med 1958; 101: 267-278.

17. Myint S, Siddell S, Tyrrell D. Detection of human coronavirus 229E in nasal washings using RNA: RNA hybridisation. J Med Virol 1989; 29: 70-73.

18. Gwaltney JM Jr, Hendley O, Hayden FG, et al. Updated recommendations for safety-testing of viral inocula used in volunteer experiments on rhinovirus colds. Prog Med Virol 1992; 39: 256-263.

19. Sterk PJ, Fabbri LM, Quanjer PH, et al. Airway 
responsiveness. Standardized challenge testing with pharmacological, physical and sensitizing stimuli in adults. Eur Respir J 1993; 6: S53-S83.

20. Myint S, Johnston S, Sanderson G, Simpson H. Evaluation of nested polymerase chain methods for the detection of human coronaviruses $229 \mathrm{E}$ and OC43. Mol Cell Probes 1994; 8: 357-364.

21. Koren HS, Hatch GE, Graham DE. Nasal lavage as a tool in assessing acute inflammation in response to inhaled pollutants. Toxicology 1990; 60: 15-25.

22. Kraaijeveld CA, Reed SE, Macnaughton MR. Enzyme-linked immunosorbent assay for detection of antibody in volunteers experimentally infected with human coronavirus strain 229 E. J Clin Microbiol 1980; 12: $493-497$.

23. Knudson RJ, Slatin RC, Lebowitz MD, Burrows B. The maximal expiratory flow-volume curve. Normal standards, variability, and effects of age. Am Rev Respir Dis 1976; 113: 587-600.

24. Akerlund A, Greiff L, Andersson M, Bende M, Alkner U, Persson CG. Mucosal exudation of fibrinogen in coronavirus-induced common colds. Acta Otolaryngol 1993; 113: 642-648.

25. Callow KA, Parry HF, Sergeant M, Tyrrell DA. The time course of the immune response to experimental coronavirus infection of man. Epidem Inf 1990; 105: $435-446$.

26. Bradburne AF, Bynoe ML, Tyrrell DA. Effects of a "new" human respiratory virus in volunteers. $B M J$ 1967; 3: 767-769.
27. Schellenberg RR. Mechanisms of airway hyperresponsiveness. In: Page CP, Gardiner PJ, eds. Airway Hyperresponsiveness: Is It Really Important For Asthma? Oxford, Blackwell Scientific, 1999; pp. $33-$ 55.

28. Trigg CJ, Nicholson KG, Wang JH, et al. A comparison of atopic and non-atopic individuals. Clin Exper Allergy 1996; 26: 665-676.

29. Folkerts G, Busse WW, Nijkamp FP, Sorkness R, Gem JE. Virus-induced airway hyperresponsiveness and asthma. Am J Respir Crit Care Med 1998; 157: $1708-1720$.

30. Jacoby DB, Fryer AD. Interaction of viral infections with muscarinic receptors. Clinical \& Exper Allergy 1999; 29: S59-S64.

31. Macek V, Hogg JC. The persistence of respiratory viruses in asthma: The host response in viral bronchiolitis and asthma. Eur Respir Rev 1998; 8: 1108-1110.

32. Pizzichini MMM, Pizzichini E, Efthimiadis A, et al. Asthma and natural colds. Inflammatory indices in induced sputum: A feasibility study. Am J Respir Crit Care Med 1998; 158: $1178-1184$.

33. Gern JE, Vrtis R, Kelly EA, Dick EC, Busse WW. Rhinovirus produces nonspecific activation of lymphocytes through a monocyte-dependent mechanism. J Immunol 1996; 157: 1605-1612.

34. Gern JE, Galagan DM, Jarjour NN, Dick EC, Busse WW. Detection of rhinovirus RNA in lower airway cells during experimentally induced infection. $\mathrm{Am}$ J Respir Crit Care Med 1997; 155: 1159-1161. 